\title{
Spolno nadlegovanje v šolah: lekcije, potencial in omejitve pristopa »aktivnih opazovalcev«
}

\author{
Vlasta Jalušič
}

$\mathrm{P}$ ristop »aktivnih opazovalcev« (active bystander) je znana praksa posredovanja v primerih spolnih ali drugih oblik nadlegovanja (na podlagi rase, invalidnosti itd.). Osredotoča se na priče nadlegovanja in nasilja, ki se kot opazovalci na dejanja ne odzovejo (prim. Banyard et al., 2009). Pristop poskuša izboljšati pripravljenost posameznikov, da reagirajo na diskriminatorna dejanja in nasilne situacije, $\mathrm{v}$ katere so vpleteni drugi, ter s tem okrepiti odgovornost povzročiteljev in skupnosti. Za ta namen pa morajo biti posamezniki dodatno opolnomočeni in spodbujeni $\mathrm{k}$ večji angažiranosti. Članek premišlja potencial, izzive in omejitve pristopa aktivnih opazovalcev kot celovitega »orodja « za preprečevanje spolnega nadlegovanja v šolah. Na osnovi izkušnje mednarodnega projekta v štirih državah EU (Malta, Portugalska, Slovenija, Združeno kraljestvo), v katerem je šest partnerjev $\mathrm{v}$ dveh letih $\mathrm{v}$ dvanajstih šolah razvilo, pilotiralo, implementiralo in ovrednotilo program aktivnega opazovalca, analizira njegov potencial in omejitve za slovenske šole.

\section{Spolno nadlegovanje $\mathrm{e}^{\mathrm{x}}$}

Termin spolno nadlegovanje (sexual harassement) je nastal $\mathrm{v}$ sedemdesetih letih prejšnjega stoletja $\mathrm{v}$ povezavi $\mathrm{z}$ nadlegovanjem na delovnem mestu (MacKinnon 1979). Spolno nadlegovanje so začeli zaznavati tudi drugod, denimo $\mathrm{v}$ šolah in na univerzah (Hill in Kearl, 201; FRA, 2014; Hester and Lilley, 2016; Vera-Gray, 2016). Definicije spolnega

$\mathrm{V}$ uvodnem delu se neposredno opiram na pregled literature, ki je bil napisan za namene projekta Bystanders (prim. Magalhães et al., 20I7), hkrati pa tudi na Hill in Kearl (20II), na Vera-Gray (2016) ter na študijo konteksta Slovenije (Jalušič et al., 2017). 
nadlegovanja niso enotne. Eno od najelementarnejših opredelitev je podala Catherine MacKinnon (1987), ko je zapisala, da gre za obliko spolne diskriminacije, ki se dogaja, kadar se vrši spolni pritisk na nekoga, ki se temu ne more upreti. Fitzgerald et al. (1995) razlikujejo tri vrste spolnega nadlegovanja: spolno nasilje, nezaželeno spolno pozornost in spolno nadlegovanje. Istanbulska konvencija spolno nadlegovanje opisuje kot »vsako obliko neželenega verbalnega, neverbalnega ali fizičnega spolnega dejanja z namenom ali posledico prizadeti dostojanstvo osebe, zlasti kadar gre za ustvarjanje zastraševalnega, sovražnega, ponižujočega, sramotilnega ali žaljivega okolja « (MKPNZND, 2014).

Eno od ključnih vprašanj pri definiranju in identificiranju spolnega nadlegovanja je, do kakšne mere lahko vnaprejšnje definicije sploh zajamejo njegovo dejansko izkustveno realnost. Obstaja namreč težnja, da se spolno nadlegovanje razume kot »izreden « pojav in ne kot vsakodnevni izraz razmerij moči med spoloma, ki se lahko manifestira v različnih situacijah in na več načinov. Najširše je spolno nadlegovanje v kontekstu šole definirano kot »nezaželena spolna pozornost, ki jo izkusijo številni adolescenti in ne vključuje samo fizičnih kontaktov, kot so denimo poljubljanje, objemanje in dotikanje, ampak tudi nefizične kontakte, kot so denimo spolne pripombe, šale, geste ali pogledi, kazanje eksplicitnih spolnih vsebin, sporočil ali zapisov ter razširjanje govoric s spolno vsebino « (de Lijster et al., 2016). Vendar so spolno nadlegovanje lahko tudi ravnanja, ki niso nujno videna kot neposredno »seksualna« (prim. Magalhães et al., 2017). Fiona Vera-Gray (2016: II) opisuje primere, ki jih je težko definirati kot spolno nadlegovanje, če uporabljamo formalne definicije, a kljub temu »predstavljajo posebno uspoljeno izkušnjo, ki jo ženske doživljajo ob srečanju z neznanimi moškimi $\ll$, denimo na javnih prostorih. Veliko situacij, ki sicer ne figurirajo kot »spolne« ali kot »nadlegovanje«, je tako zelo normaliziranih in naturaliziranih, da so spregledane in jih le redko identificirajo kot nadlegovanje (ibid.). Nekatere avtorice so zato predlagale, da ne govorimo o »spolnem «, ampak »seksističnem nadlegovanju « (Epstein, 1997), saj gre predvsem za specifično diskriminatorno naravo dejanja, ki je povezano z drugimi formami nasilja nad ženskami kot vzrokom in posledico spolne neenakosti. Liz Kelly (1988) in Elisabeth Anne Stanko (1990) sta spolno nadlegovanje konceputalizirali kot »vsiljevanje « in na tej osnovi Vera-Gray opredeli nadlegovanje kot »namerno dejanje vsiljivega stopanja na neko mesto in vdora $\mathrm{v}$ situacijo, $\mathrm{v}$ katero nekdo ni povabljen, z motečim učinkom « (Vera-Gray, 2016: I4).

Poleg medvrstniškega nasilja je $\mathrm{v}$ šolah že dalj časa tematiziran in dokumentiran tudi obstoj spolnega nadlegovanja (Meyer, 2008; Hill in Kearl, 20II; Lundgren in Amin, 2015; Women and Equalities Committee, 
2016). Pogosteje se pojavlja v srednjih šolah, vendar je značilno tudi za osnovne šole. Neredko ga obravnavajo v okviru bolj spolno nevtralnega medvrstniškega ustrahovanja in nasilja (Timmerman, 2003). Vendar politike in ukrepi, ki se ukvarjajo z ustrahovanjem in medvrstniškim nasiljem, ne morejo zares nasloviti spolnega nadlegovanja, tudi kadar ga eksplicitno opredelijo kot eno od oblik nasilja (prim. Hill in Kearl, 2orr; Charmaraman et al., 2013). Ti ukrepi se namreč ne dotaknejo predpisanih heteronormativnih spolnih vlog in spolne neenakosti, ki predstavljata podlago tovrstnega ravnanja (Meyer, 2008). Hill in Kearl (2011) ugotavljata, da lahko dogodki, ki se zdijo na videz nepomembne šale, spolne pripombe ali označevanje nekoga za homoseksualca, pomembno vplivajo na emocionalno počutje učencev in dijakov ter na celotno klimo v šoli. Obstoječe raziskave o spolnem nadlegovanju in spolnem nasilju v šolah ugotavljajo, da se spolno nadlegovanje deklet najpogosteje sprejema kot del vsakdanjosti ter da ga učitelji dojemajo predvsem kot »zafrkancijo « (Women and Equalities Committee, 2016: 3). Dejansko gre za normalizacijo nadlegovanja, saj niti šola niti širše okolje ne storita nobenih korakov za preprečevanje takšnega vedenja.

Feministične študije spolno nadlegovanje razumejo kot izraz hegemonske moškosti (Connell, 20I2), ki se v vsakdanjem življenju izraža na različne načine in zajema tako fizično nasilje kot druga vsiljiva dejanja. Nadlegovanje zaobsega dejanja dominacije in poniževanja, ki na eni strani izhajajo iz obstoječih spolnih norm, hkrati pa jih dodatno utrjujejo. Verbalno nasilje je najpogostejša oblika spolnega nadlegovanja in vključuje seksualizirane šale ter pripombe (Hill in Kearl, 2orı; Magalhães et al., 2007). Neverbalno spolno nadlegovanje se manifestira kot ogledovanje in/ali seksualizirane geste. Socialna omrežja in novi elektronski mediji omogočajo še hitrejše razširjanje seksualnih govoric, pa tudi eksplicitnih seksualnih podob, kar lahko ima posebej hude posledice za prizadete osebe, pri čemer novi mediji ohranjajo in dodatno krepijo »stare prakse « v novem kontekstu (Hill in Kearl, 20II).

Raziskava Agencije za temeljne pravice (FRA) ugotavlja, da je spolno nadlegovanje najbolj pogosta oblika nasilja nad dekleti in ženskami $\mathrm{v}$ 28 državah EU (FRA, 20I4). Ocena je, da je 83-102 milijona žensk nad petnajstim letom starosti (45-55\% v državah članicah, v Sloveniji pa 44) izkusilo spolno nadlegovanje. Številke so najverjetneje še višje, saj to starostno obdobje zajema samo del časa šolanja deklet. Podatki kažejo, da dekleta doživljajo spolno nadlegovanje veliko pogosteje kot fantje. Šolsko okolje, ki to tolerira, lahko postane za dekleta sovražno. Zaradi slabih izkušenj se dekleta bolj kot fantje bojijo vpliva spolnega nadlegovanja na njihova življenja (ibid.). 
Žrtve spolnega nadlegovanja občutijo številne posledice, ki so bodisi neposredne, kot so denimo anksioznost, slabša koncentracija in uspešnost $\mathrm{v}$ šoli ter na delovnem mestu, absentizem, ker se izogibajo povzročiteljem, zloraba drog in alkohola, vse tja do samomora. Šola, v kateri se dogaja spolno nadlegovanje, preneha biti varen prostor za učence in učenke, kar vpliva na šolsko skupnost kot celoto ter na sam učno-vzgojni proces (Meyer, 2008; Hill in Kearl, 20II). Študija FRA (2014) navaja občutke jeze, nejevolje, zadrege in sramu ter posledice, kot so večja ranljivost, strah, težave $\mathrm{v}$ odnosih, neuspešnost in depresija. Medtem ko nekateri prizadeti, predvsem moški, kažejo manjšo ranljivost $v$ primerih spolnega nadlegovanja, pa je vzorec pri homoseksualnih moških podoben kot pri ženskah. Še posebej hude posledice ima nadlegovanje za tiste, ki se nahajajo na podrejenih položajih (prim. Magalhães et al., 2017). Normalizacija nadlegovanja implicira, da odgovornost navsezadnje pade predvsem na učence in učenke ter da se dekleta, ki so bolj izpostavljena, zaradi tolerance do spolnega nadlegovanja nad njimi počutijo vredna manj kot fantje, hkrati pa se nič ne spremeni.

Liz Kelly (1988) je umestila nadlegovanje $\mathrm{v} \gg$ kontinuum nasilja $\ll$ in Raewyn Connell (2012) govori o »ustrahovanju žensk, ki je prisotno v celotnem razponu od občudujočih žvižgov na ulici, do spolnega nadlegovanja na delovnem mestu, do posilstva in družinskega nasilja, do umorov žensk, ki jih izvedejo patriarhalni ,lastniki', na primer ločeni nekdanji možje« (str. 126-7). Connell ugotavlja, da se nasilje nad ženskami in dekleti, ki se manifestira tudi kot spolno nadlegovanje, dogaja v družbenih in kulturnih kontekstih, ki temeljijo na patriarhalnih sistemih. Simbolne reprezentacije, verovanja in prakse, ki se tako reproducirajo, ohranjajo heteronormativni red in privilegirajo hegemonsko moškost. Intervencije, ki hočejo biti smiselne in učinkovite, bi morale tovrstne družbene reprezentacije in prakse spreminjati ter ustvariti razmere, ki omogočajo (večjo) spolno enakost.

V kontekstu preprečevanja nasilja nad ženskami in dekleti je zato pomembno, da se intervencija ne osredotoča samo na individualne povzročitelje ali žrtve (in da ne naslavlja samo neposrednih posledic dejanj nasilja in preprečevanja nadaljnjega nasilja), ampak na razvijanje strategij in ukrepov, ki spodbujajo družbene, kulturne in politične spremembe, ki krepijo enakost, pravičnost in spoštovanje človekovih pravic. V nasprotnem primeru zanemarimo okoliščine in razloge, ki so osnova pojavljanja nasilja. Pomembno je okrepiti razumevanje vzrokov in posledic nasilja, ki temelji na spolu in heteronormativnosti, ter spreminjati odnose in transformirati ravnanja, hkrati pa izboljševati strategije odgovorov na nasilje (Magalhães et al., 2007). 
Prav ta moment je odločilen $\mathrm{v}$ programih, ki so usmerjeni $\mathrm{v}$ skupnost in se ukvarjajo z ukrepanjem opazovalcev (bystanders). Vzgojnoizobraževalni programi so najbolj pogosto uporabljane strategije primarne intervencije in predvsem $\mathrm{v}$ šolah se kažejo kot potencialno najbolj učinkoviti za doseganje družbenih in kulturnih sprememb. Kljub temu ne dajejo enovitih rezultatov, hkrati pa običajno tudi niso ovrednoteni na dolgi rok (prim. Lundgren in Amin, 2015). Večina programov izhaja iz podmene, da dekleta in fantje potrebujejo različen pristop ter obravnavajo temo nasilja in nadlegovanja $\mathrm{v}$ skupinah, ki so ločene po spolu. Past takšnega pristopa je, da lahko postavimo nasproti dve skupini, moške in ženske, ter identificiramo vse ženske kot žrtve in vse moške kot potencialne storilce. To lahko rezultira v obrambni strategiji, hkrati pa okrepi obstoječe spolne norme, ki jih tovrstni programi v resnici poskušajo spreminjati (Schewe in O'Donohue, 1993; Carmody, 2006). Obstaja tudi dodatna nevarnost, da se breme odgovornosti za zaščito preloži na ramena deklet. Programi, ki spodbujajo odziv opazovalcev, se poskušajo temu izogniti in težijo $\mathrm{k}$ temu, da se udeleženci identificirajo z žrtvami. Problematičnih ravnanj zato ne definirajo vnaprej, ampak spodbujajo, da udeleženci, moški in ženske, $v$ konkretnih situacijah prepoznajo takšna ravnanja glede na to, kako jih sami doživljajo.

\section{Spolno nadlegovanje in nasilje v šolah v Sloveniji}

V Sloveniji so raziskave in podatki o spolnem nadlegovanju še vedno skopi. Analize se, podobno kot marsikje drugod, v glavnem osredotočajo na delovno mesto. Študij, ki se bi posvečale izključno spolnemu nadlegovanju (in spolnemu nasilju) v šolah, tako rekoč ni, razen nekaterih drobcev in izsledkov v diplomskih delih. Čeprav je zaradi majhnega števila relevantnih raziskav v šolah v Sloveniji težko delati zaključke o spolnem nadlegovanju, bom za orientacijo navedla vsaj nekaj obstoječih podatkov iz študij o spolnem nasilju v šolah, ki pa niso enoznačni.

Ena od analiz, ki se ukvarja s spolnim nasiljem (avtorica je intervjuvala IIs dijakov in dijakinj, starih I5-19 let, na eni od slovenskih srednjih šol - prim. Bojc, 2007), ugotavlja, da dijakom in dijakinjam primanjkuje znanja in zavedanja o spolnem nasilju ter da ga niso sposobni prepoznati (še posebej ne nasilja, ki ni fizično). Samo $27 \%$ intervjuvanih dijakov je dejalo, da niso izkusili nobenega spolnega nasilja v zadnjih dveh letih. Večina je izkusila neverbalno spolno nasilje (geste), povzročitelji so bili zvečine starejši in moški, žrtve pa pretežno ženske. Samo 7 \% dijakov ni bilo priča nobeni obliki spolnega nasilja v dveh letih pred raziskavo. 6r \% je dejalo, da so bili žrtve verbalnega spolnega nasilja, 49 \% neverbalnega in 2r \% fizičnega spolnega nasilja. Povzročitelji so bili bodisi iste starosti 
(46\%) ali starejši kot žrtve ( $53 \%$ ), zvečine moški (76 \%); večina med njimi so bili dijaki iste šole ali ljudje izven šole. Največ spolnega nadlegovanja se je dogajalo po šoli ali v odmorih med poukom. Manj kot $30 \%$ dijakov je trdilo, da bi se uprli povzročiteljem spolnega nasilja, nihče od njih pa o teh dogodkih ni poročal pristojnim institucijam. Največ dijakov o spolnem nasilju ni govorilo z nikomer, razen s svojimi prijatelji. Le peščica se je o tem, da so izkusili spolno nasilje, zaupala učitelju ali učiteljici, medtem ko sta dva dijaka poročala, da so učitelji ta dejanja umestili med $\gg$ normalna«. $86 \%$ dijakov je dejalo, da med šolskim poukom niso bodisi nikoli ali pa zelo redko razpravljali o spolnem nasilju. Večina dijakov je menila, da bi morala biti problematika spolnega nasilja bodisi del kurikuluma ali pa podana kot kratek predmet v šoli. Spolno nasilje je torej resen problem, $s$ katerim bi se v šolah morali posebej ukvarjati. Hkrati je mogoče sklepati, da šolsko osebje nima dovolj znanja, zavedanja in sposobnosti, da bi se odzivali in preprečevali spolno nasilje $\mathrm{v}$ šolah.

Deset let stara empirična raziskava o nasilju $\mathrm{v}$ šolah (Lešnik Mugnaioni et al., 2009), ki je zajela 262 učiteljev in drugo osebje, je ob psihološkem, fizičnem, verbalnem, emocionalnem in ekonomskem nasilju deloma obravnavala tudi spolno nasilje. Vrste nasilja, ki so jih avtorji sicer raziskovali, so vključevale medvrstniško nasilje, nasilje dijakov nad učitelji, nasilje učiteljev nad dijaki, nasilje med učitelji, med učitelji in starši ter družinsko nasilje. Spolno nasilje predstavlja posebno vrsto nasilja, ki ga je mogoče najti med vsemi naštetimi oblikami nasilja. Avtorji/-ce se niso posebej posvečali spolnemu nadlegovanju, vendar pa omenijo definicijo Sveta Evropske unije. Ta pravi, da je »spolno nadlegovanje nezaželeno dejanje spolne ali druge narave, ki ogroža dostojanstvo žensk in moških na delovnem mestu; če je takšno ravnanje vsiljivo, neprimerno in sovražno za tistega, na kogar se nanaša« (Council Resolution, 1990). Avtorji posebej izpostavljajo, da je mogoče v kontekstu spolnega nadlegovanja zaznati več vrst nasilja, ki je lahko fizično, verbalno ali neverbalno (Lešnik Mugnaioni et al., 2009: 30). ${ }^{2}$

Nasilje so najpogosteje zaznali razredniki ali drugi učitelji, o njem pa naj bi poročali drugi dijaki (ne žrtve). Šole o primerih nasilja zelo redko informirajo relevantne institucije, najpogosteje pa se s primeri ukvarjajo šolsko svetovalno osebje, socialni delavci/-ke ali učitelji/-ce. Med vsemi

2 Dobesedna definicija Direktive Sveta 2002/73/EC - enaka obravnava, z dne 23. septembra 2002, ki je dopolnila Direktivo Sveta 76/207/EEC in je prevzeta v slovensko zakonodajo v Zakonu o delovnih razmerjih, pravi, da se spolno nadlegovanje dogaja povsod, kjer » pride do nezaželenega verbalnega, neverbalnega ali fizičnega ravnanja spolne narave z namenom ali učinkom kršiti dostojanstvo osebe (Direktiva Sveta 2002/73/EC - enaka obravnava, z dne 23. septembra 2002). 
oblikami nasilja med dijaki v srednjih šolah je najmanj zaznano spolno nasilje, čeprav se je avtorjem zdel visok delež tistih, ki ga zaznavajo občasno, pogosto ali celo zelo pogosto (skoraj $20 \%$ ). Vendar raziskava ni specificirala, za kakšne oblike spolnega nasilje gre, in avtorji domnevajo, da je spolnega nasilja na šolah več, kot kaže raziskava (Lešnik Mugnaioni et al., 2009: 149-190).

Slovarček študije vsebuje tudi termin »opazovalec« (bystander), ki označuje tiste osebe, ki so videle ali zaznale nasilno dejanje. Omenjena je tudi $\gg$ priča «, kar je sicer pravna definicija in pomeni posameznika/-co, ki priča $\mathrm{v}$ sodnem procesu oziroma kriminalistični preiskavi. Termin opazovalec je dojet kot bolj nevtralen, saj ni a priori vezan na delovanje ali intervencijo, čeprav so metode preventive proti nasilju v šoli, družini ali na delovnem mestu usmerjene predvsem na aktivne opazovalce in jih ne dojemajo kot pasivne ali indiferentne do nasilnih dogodkov. Intervencije težijo $\mathrm{k}$ temu, da ustvarijo aktivne subjekte, ki bodo spregovorili o nasilju, intervenirali ali se postavili za žrtve - skratka, ki bodo intervenirali v (nasilne) dogodke (Lešnik Mugnaioni et al., 2009: 36). Vendar pa preventivne metode in modeli, ki jih za primer slovenskih šol naštevajo avtorji te študije, ne vključujejo specifičnih modelov, ki bi se ukvarjali s spolnim nadlegovanjem ali spolnim nasiljem $\mathrm{v}$ šolah.

\section{Politike proti spolnemu nadlegovanju v srednjih šolah v Sloveniji ${ }^{3}$}

Po obstoječih podatkih nobena od srednjih šol v Sloveniji nima samostojne politike proti spolnemu nadlegovanju. Vprašanje »spolnega nasilja je vključeno v splošno politiko proti ustrahovanju, zlasti v Protokol ob zaznavi in za obravnavo medvrstniškega nasilja v vzgojno-izobraževalnih zavodih, ki ga je pripravil Zavod za šolstvo; le-ta vključuje tudi navodila in priročnik. Protokol poudarja, da mora vsak vzgojno-izobraževalni zavod (šola) obravnavati različne oblike nasilja in se nanje odzvati. Hkrati poudarja tudi, da zaposleni pogosto niso strokovno usposobljeni (na zelo praktični ravni) za to, kako učinkovito obravnavati nasilje v vzgojno-izobraževalnih zavodih (Zavod RS za šolstvo, 2016). Protokol spolnega nadlegovanja ne opredeljuje izrecno, temveč ga opisuje kot obliko spolnega nasilja: navaja namigovanje na spolnost in šale s spolno vsebino, opolzko gestikuliranje in govorjenje, nadlegovanje zaradi pripadnosti spolu, nagovarjanje na spolnost, prikazovanje pornografskega materiala, otipavanje, zalezovanje, spolni napad itd. 
Protokol opredeljuje ustrahovanje, žrtve ustrahovanja in opazovalce. Opazovalci so definirani kot »vrstniki, ki zaznajo nasilje med vrstniki, ga neposredno opazujejo ali celo spodbujajo k nadaljevanju nasilja, a vanj aktivno ne posegajo, ne izvajajo nasilja, a žrtve ne zaščitijo «. Opredeljeni so tudi različni vzroki za takšno vedenje žrtev: »strah pred povzročiteljem, ne želijo se izpostaviti, ne zaupajo, da bodo odrasli ustavili nasilje, slabe izkušnje iz preteklosti, menijo, da to ni njihov problem, tiha identifikacija s povzročiteljem in drugo « (ibid., 13).

Protokolu so priložena navodila, ki določajo ravnanje zaposlenih v javnih in zasebnih vzgojno-izobraževalnih zavodih, ki izvajajo javno veljaven (uradni) program ob zaznavi in obravnavi medvrstniškega nasilja (Zavod RS za šolstvo, 2016a). Navodila so razdeljena na takojšnje intervencije in procesne intervencije. Ključni akterji so učitelji, šolske svetovalne službe in vodstvo vzgojno-izobraževalnih zavodov: ravnatelj ali ravnateljev pomočnik. Spodbuja se sodelovanje z drugimi organi, kot so policija, centri za socialno delo in nevladne organizacije.

Šole imajo običajno tudi pravila (šolske rede), ki določajo pravice, obveznosti in prepovedi za dijake/-inje $\mathrm{v}$ času pouka. Ta pravila so usklajena $z$ letnim delovnim načrtom šole, vendar po dostopnih informacijah ni sistematičnih programov za obravnavanje spolnega nadlegovanja ali spolnega nasilja v šolah, zlasti v smislu preprečevanja, obveščanja, krepitve ozaveščenosti ali odpravljanja nadlegovanja. Nekatere prvine možnih intervencijskih shem so, kot je prikazano zgoraj, vključene v politike o medvrstniškem ustrahovanju, vendar pri tem ne gre za celovit pristop. Šole uporabljajo splošni pravilnik o šolskem redu, ki ga vsako leto sprejme Ministrstvo za šolstvo, znanost in šport. Ta določa, da šola z vzgojnim delovanjem ozavešča dijake o različnih temah, vključno $\mathrm{z} \gg$ različnimi vrstami nasilja«, vendar ne omenja niti spolnega nasilja niti spolnega nadlegovanja (Pravilnik o šolskem redu v srednjih šolah, 2018).

\section{Projekt Bystanders/Opazovalci: (Spre)govori}

Kot navaja Agencija za temeljne pravice (FRA, 2OI4), je spolno nadlegovanje ena od prevladujočih oblik nasilja nad ženskami v Evropi. Kljub temu je področje preventive slabo razvito tako v celotni EU kot tudi v Sloveniji. Dvoletni raziskovalni in akcijski projekt Bystanders (2016-2018), ki smo ga izvajali v Angliji, na Portugalskem, Malti in v Sloveniji, se je zato usmeril na preventivno ozaveščanje mladih, $\mathrm{z}$ namenom spodbuditi njihovo odločnost in voljo, da delujejo kot opazovalci, ki lahko spremenijo družbeno klimo in kulturo normalizacije ter toleriranja spolnega nadlegovanja. Pristop »aktivnih opazovalcev« (active bystander) poskuša izboljšati pripravljenost posameznikov_ic, da reagirajo na diskriminatorna dejanja 
in nasilne situacije, $\mathrm{v}$ katere so vpleteni drugi, ter $\mathrm{s}$ tem okrepiti odgovornost povzročiteljev_ic in skupnosti. Za ta namen pa morajo biti posamezniki_ce dodatno opolnomočeni_e in spodbujeni_e k večji angažiranosti. V programu (Spre)govori smo ubrali pot vsešolskega šolskega pristopa, ki poskuša identificirati načine, kako lahko vsi udeleženci_ke v šolskem prostoru (dijaki_nje, učitelji_ce, drugi_e zaposleni_e na šoli) in subjekti šolskega kurikuluma spremenijo kontekst, v katerem sta spolno nadlegovanje ter prisotnost spolne neenakosti normalizirana.

Cilji projekta (http://www.bystanders.eu/) so bili povečati znanje in okrepiti ozaveščenost o spolnem nadlegovanju $\mathrm{v}$ šolah; razviti in izvajati program usposabljanja dijakov_inj in zaposlenih na šolah za posredovanje v primerih spolnega nadlegovanja; okrepiti motivacijo opazovalcev_k za ustavljanje spolnega nadlegovanja $\mathrm{v}$ šolah ter razviti šolske in lokalne politike ter protokole proti spolnemu nadlegovanju.

Po Potterju in drugih (2009) lahko program za opazovalce_ke opredelimo kot:

Medvrstniški izobraževalni program, ki udeležence nauči prepoznavati situacije, ki bi lahko privedle do spolnega nasilja, in posredovati varno, nenasilno in prosocialno pred incidentom, med njim, po njem s prijatelji, znanci ali neznanci (Potter in drugi, 2009: 108).

Projekt je vključeval splošne aktivnosti generiranja znanja in izvajanje programa usposabljanja $z$ dijaki_njami in zaposlenimi na šolah, ki ga je na predlog britanskih raziskovalk celotna mednarodna ekipa poimenovala »(Spre)govori«. Metoda je zajemala: $\mathrm{I}$ ) aktivnosti za globlje razumevanje nacionalnih kontekstov in družbenih reprezentacij dijakov_inj in zaposlenih: pregled literature in opis nacionalnih kontekstov; 2) izvedbo pripravljalnih fokusnih skupin kot raziskave za pripravo programa; 3 ) izbiro šol in delo z osebjem za pripravo programa opazovalcev; 4) razvitje in pilotiranje programa intervencije opazovalcev; 5)izvedbo programa $\mathrm{v}$ treh šolah; 6) monitoring in evalvacijo učinkov ter predstavitev rezultatov ustvarjalcem politik.

Da bi bolje razumeli obstoječe predstave o spolnem nadlegovanju, smo po pregledu literature in politik proti spolnemu nadlegovanju opravili raziskavo konteksta. Raziskava ciljnih skupin je bila izvedena z dijaki_ njami, učitelji_cami ter drugim šolskim osebjem. V fokusnih skupinah smo razpravljali o tem, kaj je spolno nadlegovanje, komu se dogaja, kdo so nadlegovalci_ke, ali je $\mathrm{v}$ šolah prisotno spolno nadlegovanje, kaj storijo tisti, ki vidijo spolno nadlegovanje, in kaj bi lahko storili. Te pogovore smo posneli in analizirali, kaj šteje za spolno nadlegovanje in kako udeleženci dojemajo možne intervencije opazovalcev_k. Na tej osnovi je bil 
pripravljen pilotni program. Aktivnosti, zamisli in primere spolnega nadlegovanja smo črpali iz fokusnih skupin. Program je bil jeseni 2016 preizkušen $\mathrm{v}$ enem razredu in na podlagi tega je bil izdelan končni program »(Spre)govori«. Ta program (glej Tabelo 3 ) je bil v vsaki državi izveden v treh izbranih šolah hkrati (med januarjem in septembrom 2017). V celotnem projektu je tako sodelovalo 12 šol, 429 dijakov ter I09 zaposlenih na srednjih šolah. ${ }^{4}$

Za izvedbo projekta v Sloveniji smo izbrali po eno šolo izmed treh glavnih vrst srednjih šol, tako iz prestolnice kot tudi iz ene od slovenskih regij. Zasebnih šol nismo vključili, saj so skoraj vse šole v Sloveniji javne in jih financira država, med šolskimi organizacijami ali pravili v javnih šolah pa so le zanemarljive razlike. Glavne razlike med šolami v Sloveniji se oblikujejo glede na izobraževalni cilj šole, ki je odvisen od usmeritve (poklicne, tehnične, splošne). Šole, ki smo jih vključili (gimnazija, splošna strokovna in poklicna), se med seboj razlikujejo glede na stopnjo splošnega, še zlasti družboslovnega znanja dijakov_inj, kar je odvisno tako od predznanja kot tudi od učnega načrta, ki jim zagotavlja več ali manj predmetov, ki obravnavajo širše izobraževalne cilje. Razlikujejo se tudi glede spolne sestave ali števila fantov in deklet $\mathrm{v}$ razredih, 5 prav tako pa tudi, kot kažejo nekatere predhodne študije, glede socialne in etnične sestave dijakov. $^{6}$

Program je dostopen na: http://www.bystanders.eu/bystanders-programme/.

Več vpisanih deklet je v šolah s splošnimi srednješolskimi programi (60\%), v srednjem tehničnem in strokovnem izobraževanju je bilo 2017 vključenih $46 \%$ deklet. V poklicno in strokovno izobraževanje je vključenih več fantov kot deklet. Skoraj tri četrtine ( 73 \%) vseh fantov se odloči za te programe, med katerimi so najprivlačnejša tehnična področja in računalništvo. Dekleta se manj odločajo za poklicne in strokovne programe, najpogosteje pa izberejo zdravstvene programe, osebne storitve in ekonomske programe. Razlogi za to po našem mnenju niso dovolj raziskani, četudi nekateri avtorji in avtorice menijo, da so ženske v sedanji šolski ureditvi »privilegirane, saj dosegajo višje rezultate in so jim s tem širše odprta vrata pri vstopanju v nadaljnje stopnje izobraževanja, kar je mogoče pojasniti z njihovo odgovornostjo do dela in učenja . Zdi se, da ta hipoteza premalo upošteva druge dimenzije spolne neenakosti, ki bi morda lahko bolje pomagale razložiti tudi to, da imajo $\mathrm{v}$ srednjih poklicnih in strokovnih šolah, v katere so vpisani predvsem fantje, $\gg$ učitelji s fanti več ne le učnih, temveč tudi disciplinskih težav« (prim. Kroflič in Peček Čuk, 2009: 19).

Na podlagi rezultatov projekta PISA je bila postavljena ocena »o visoki socialno-kulturni heterogenosti med različnimi vrstami srednjih šol ter o socialno-kulturni homogenosti znotraj posamezne srednje šole«, kar se povezuje s socialnim izključevanjem (ibid.). 
Tabela I: Število udeleženih dijakov v vsaki skupini oziroma razredu v Sloveniji.

\begin{tabular}{|c|c|c|c|c|}
\hline Šola & Število udeleženih na skupino & Fantje & Dekleta & Skupaj \\
\hline \multirow{2}{*}{$\frac{\vec{\pi}}{0}$} & Razred A & 8 & 23 & 31 \\
\hline & Razred B & $2 \mathrm{I}$ & 8 & 29 \\
\hline \multirow{2}{*}{$\frac{\sqrt{3}}{3}$} & Razred A & 23 & IO & 33 \\
\hline & Razred B & 9 & 20 & 29 \\
\hline \multirow{2}{*}{$\frac{\pi}{\frac{\pi}{0}}$} & Razred A & 13 & 3 & 16 \\
\hline & Razred B & 4 & 19 & 23 \\
\hline $\begin{array}{l}\overline{\vec{n}} \\
\overrightarrow{\vec{n}} \\
\frac{\vec{n}}{n}\end{array}$ & Vsi & 77 & 76 & 162 \\
\hline
\end{tabular}

Tabela 2: Število udeleženih zaposlenih.

\begin{tabular}{lcccc} 
& Šola I & Šola 2 & Šola 2 & Skupno \\
Zaposleni & 4 & 10 & 16 & 30 \\
\hline
\end{tabular}

V vsaki od izbranih šol smo izvedli po tri delavnice z dijaki_njami in po dve z zaposlenimi, nadaljnje aktivnosti pa so vključevale dodatne akcije in naknadna srečanje z dijaki_njami in zaposlenimi v šolah. Delavnice (z dijaki_njami in zaposlenimi) so sicer trajale približno 90 minut, vsako posebej pa smo popisali v implementacijskem dnevniku. ${ }^{7}$

7 Delavnice je izvajal partner v projektu Društvo za nenasilno komunikacijo. Kolegicam z DNK, ki so organizirale in izvajale delavnice ter zapisovale potek implementacije, se tukaj iskreno zahvaljujem. 
Tabela 3: Aktivnosti/program delavnic z dijaki_njami.

\begin{tabular}{|c|c|c|}
\hline Srečanje & Aktivnost & Opis aktivnosti \\
\hline \multirow{2}{*}{$\begin{array}{l}\text { Prvo srečanje (ločeno po } \\
\text { spolih) }\end{array}$} & $\begin{array}{l}\text { Vinjete o spolnem nadle- } \\
\text { govanju (aktivnost Kje } \\
\text { je meja) }\end{array}$ & $\begin{array}{l}\text { Resnične situacije spolnega nadlegovanja, ki } \\
\text { smo jih identificirali v fokusnih skupinah v } \\
\text { državah v projektu, so bile opisane na karti- } \\
\text { cah (vinjetah) od I do } 8 \text {. Te vinjete so bile raz- } \\
\text { deljene dijakom_injam, vsak pa je moral opi- } \\
\text { sano situacijo označiti kot »sprejemljivo « ali } \\
» \text { nesprejemljivo, in sicer med premikanjem } \\
\text { po prostoru in položaju (»Kje se dogaja spol- } \\
\text { no nadlegovanje?«). }\end{array}$ \\
\hline & $\begin{array}{l}\text { Združeni konceptni } \\
\text { zemljevid } \\
\text { Kdo nadleguje, kje, koga, } \\
\text { zakaj ni odziva, kdo naj } \\
\text { se odzove, kako se poču- } \\
\text { ti žrtev itd. }\end{array}$ & $\begin{array}{l}\text { Dijaki_nje, organizirani_e v skupinah, so } \\
\text { izdelali_e zemljevide s svojimi koncepti } \\
\text { spolnega nadlegovanja. Izdelan je bil skupen } \\
\text { »konceptni zemljevid «, ki zajema koncepte, } \\
\text { ki so jih predlagali fantje in dekleta. Na dru- } \\
\text { gem srečanju so fantje in dekleta v enospol- } \\
\text { nih skupinah razpravljali o tem zemljevidu } \\
\text { glede na podobnosti in razlike. }\end{array}$ \\
\hline \multirow{3}{*}{$\begin{array}{l}\text { Drugo srečanje (ločeno } \\
\text { po spolih) }\end{array}$} & $\begin{array}{l}\text { Aktivnost } \\
\gg \text { Najverjetneje } \ll \\
\text { (stereotipi) }\end{array}$ & $\begin{array}{l}\text { Pripravljene so bile stereotipne izjave (kot } \\
\text { so na primer } \gg \text { Kdo se bo najverjetneje za- } \\
\text { pletel v pretep? «, } » \text { Kdo bo najverjetneje jo- } \\
\text { kal?«, »Kdo bo doma najverjetneje kuhal? «) } \\
\text { Udeleženci so ugotavljali, kdo je »bolj ver- } \\
\text { jetno « povezan z vsako situacijo - dekle- } \\
\text { ta ali fantje? }\end{array}$ \\
\hline & Video Opazovalci & $\begin{array}{l}\text { Predvajan je bil kratek video posnetek s pri- } \\
\text { meri ravnanja opazovalcev in na podlagi } \\
\text { ogleda in razprave so moderatorji od dija- } \\
\text { kov_inj dobili povratne informacije o tem, } \\
\text { kaj menijo, da so ovire za ukrepanje, ko pri- } \\
\text { de do spolnega nadlegovanja, in o tem, kaj bi } \\
\text { lahko storili, da bi hitreje posredovali. }\end{array}$ \\
\hline & $\begin{array}{l}\text { Igranje vlog } \\
\text { opazovalcev_k }\end{array}$ & $\begin{array}{l}\text { Dva prostovoljca (dijaka_inji) sta } \\
\text { uprizorila_i tipičen prizor spolnega nadle- } \\
\text { govanja na podlagi ene od vinjet, uporablje- } \\
\text { nih na prvem srečanju. Med igranjem vlog } \\
\text { je bilo občinstvo pozvano, da posreduje in } \\
\text { poda svoje mnenje o situaciji. }\end{array}$ \\
\hline \multirow[b]{2}{*}{ Tretje srečanje (mešano) } & Program za spremembe & $\begin{array}{l}\text { Program za ukrepanje je bil razvit s skupina- } \\
\text { mi na podlagi njihovih mnenj o ukrepih, ki } \\
\text { jih je mogoče sprejeti za preprečevanje spol- } \\
\text { nega nadlegovanja na njihovih šolah. }\end{array}$ \\
\hline & $\begin{array}{l}\text { Logotipi »Spregovori in } \\
\text { ukrepaj« }\end{array}$ & $\begin{array}{l}\text { Razdeljeni v skupine so dijaki_nje } \\
\text { pripravili_e svoje lastne besede oziroma slo- } \\
\text { gane, napisane znotraj praznega logotipa, ki } \\
\text { je zajemal vse, o čemer so razpravljali na treh } \\
\text { srečanjih projekta. }\end{array}$ \\
\hline
\end{tabular}




\begin{tabular}{ccl} 
Srečanje & \multicolumn{1}{c}{ Aktivnost } & \multicolumn{1}{c}{ Opis aktivnosti } \\
Kako so se občutki & $\begin{array}{l}\text { Dijaki_nje so morali_e dopolniti tri povedi, } \\
\text { ki so se nanašale na njihove občutke o spol- } \\
\text { nem nadlegovanju,žrtvi in nadlegovalcu } \\
\text { pred projektom in po njem. }\end{array}$ \\
\cline { 2 - 3 } Nadaljnje ukrepanje & $\begin{array}{l}\text { Kako so se misli spreme- } \\
\text { nile (del srečanja v skupi- } \\
\text { nah, ločenih po spolu) }\end{array}$ & $\begin{array}{l}\text { Dijaki_nje so opisali_e, kako so se spreme- } \\
\text { nile njihove predstave o spolnem nadlegova- } \\
\text { nju,žrtvah, nadlegovalcih in opazovalcih. }\end{array}$ \\
\hline
\end{tabular}

\section{Potek programa}

Dijaške delavnice so potekale najprej v skupinah, razdeljenih po spolu (vsaka skupina dijakov in dijakinj je imela dve ločeni delavnici). Sledile so mešane delavnice $s$ fanti in dekleti. Prvi sklop aktivnosti je bil namenjen večji ozaveščenosti in prepoznavanju spolnega nadlegovanja, zmožnosti določanja meja sprejemljivega vedenja ter razpravljanju o spolnih stereotipih ob hkratni obravnavi glavnih značilnosti spolnega nadlegovanja. Drugi sklop (izdelava konceptnih zemljevidov in igra vlog) je ponudil jasnejšo sliko o tem, zakaj dijaki_nje in učitelji_ce ne posredujejo v primerih spolnega nadlegovanja, kaj so ovire in kaj bi lahko storili. V njih so dijaki_nje poimenovali_celoten spekter situacij spolnega nadlegovanja ter relacij moči med povzročitelji, žrtvami in opazovalci. Tretji sklop je bil namenjen premisleku odziva, temu, kakšen bi odziv lahko bil, temu pa je sledilo razmišljanje o konkretnih korakih in ukrepih. Delavnice za zaposlene so sledile istim temam kot dijaške (vinjete s konkretnimi situacija$\mathrm{mi}$ ), hkrati pa so temeljile na razpravi o rezultatih dijaških delavnic (denimo konceptnih zemljevidov).

$\mathrm{Na}$ delavnicah smo na šolah spodbudili tudi več nadaljnjih aktivnosti, ki so potekale večinoma $\mathrm{v}$ dveh mesecih po zadnji delavnici. Namen je bil pripomoči k nastanku protokolov o obravnavi spolnega nadlegovanja na šolah. Dijaki_nje so svoje aktivnosti načrtovali_e na zadnji (spolno mešani) delavnici, moderatorji_ke pa so jim pomagali pri razmišljanju o tem, kaj bi bilo mogoče storiti, da bi okrepili ozaveščenost o spolnem nadlegovanju in aktivirali_e opazovalce_ke. Tudi zaposleni so bili motivirani za načrtovanje dejavnosti, zlasti za vzpostavitev protokola o tem, kako nadaljevati postopek $\mathrm{v}$ primerih spolnega nadlegovanja skupaj z dijaki_ njami. Nekatere aktivnosti so nato potekale s podporo Društva za nenasilno komunikacijo, ki je bilo glavni partner $\mathrm{v}$ slovenskem delu projekta. $\mathrm{Na}$ eni od šol so zaposleni skupaj z dijaki_njami začeli konkretno razpravo o novih pravilih o spolnem nadlegovanju, ki bi jih vključili v celostno obravnavo nasilja, ter o tem, kako bi to integrirali v šolske akte. Hkrati je potekala evalvacija programa, ki je temeljila na izpolnjenih vprašalnikih dijakov_inj in zaposlenih. 
Izsledki delavnic ter rezultati programa so večplastni. V nadaljevanju podajam opis nekaterih temeljnih opažanj iz poteka na osnovi implementacijskih dnevnikov, nato pa še glavne poudarke ter sklepno refleksijo.

\section{Rezultati programa}

Dijaki, dijakinje in zaposleni so v programu sodelovali z zanimanjem, čeprav je bila stopnja aktivnosti odvisna tako od vrste šole kot tudi od razreda in spola udeležencev. Na dijaških delavnicah je bila udeležba skoraj polna, medtem ko so bile med šolami razlike v številu zaposlenih, ki so sodelovali. Opazili smo, da so tako fantje kot dekleta izražali manj mnenj, ko so bili skupaj, kot pa v ločenih delavnicah. Na splošno so bili fantje manj aktivni, razen na eni od šol.

Med dekleti in fanti so obstajale razlike pri presoji, kaj je primerno ali neustrezno vedenje, a mnenja so variirala tudi med fanti in med dekleti. Tako pri dijakih kot tudi pri dijakinjah smo opazili prenašanje odgovornosti za nadlegovanje na žrtve, vendar to ni bil prevladujoč odnos pri skoraj nobeni od skupin. Večina deklet je postavila strožje omejitve za sprejemljivo vedenje kot fantje, hkrati pa so številna od njih dobro poznala spolno nadlegovanje.

Nekateri dijaki in dijakinje so se nagibali k obtoževanju žrtev nadlegovanja, kadar so bile domnevno »izzivalno « oblečene, medtem ko so drugi strogo zavračali možnost, da bi lahko bila izgled ali oblačenje izgovor za nadlegovanje. Dijakinje so izpostavile pomen privolitve za določena ravnanja in poudarile, da obstaja povezava med spolnim nadlegovanjem in problemom neenakomerne porazdelitve moči. Manjša skupina fantov je izrazila izrecna dvojna merila za oba spola glede ustreznega obnašanja. Spolno nadlegovanje jim je predstavljalo izkazovanje naklonjenosti in ljubezni.

Spolni stereotipi, ki so se pojavili, so bili po eni strani povezani z obtoževanjem žrtve, katere vedenje da kliče po nadlegovanju. Čeprav so dekleta in nekateri fantje prepoznavali spolne stereotipe in dvojna merila za dekleta in fante, se številni vendarle niso jasno zavedali lastnih dvojnih meril. Pojavljalo se je mnenje, da imajo fantje težave $s$ samokontrolo $\gg$ zaradi hormonov« ter da je nadlegovanje pogojeno $\mathrm{z}$ različnimi spolnimi vlogami moških in žensk ter $s$ tem povezanimi predstavami o spolnosti.

Delavnice za zaposlene so podale podobno sliko kot tiste za dijake_ inje. Eden od stereotipov med nekaterimi (moškimi) zaposlenimi je bil, da do spolnega nadlegovanja prihaja $\mathrm{v}$ parkih, $\mathrm{v}$ velikih mestih in drugje, podobno, kot so nekateri fantje na delavnicah o spolnem nadlegovanju in spolnem nasilju govorili kot o nečem, kar se ne dogaja v njihovi okolici. Zaposleni so na prvih delavnicah menili, da s spolnim nadlegovanjem 
nimajo izkušenj, pozneje pa se je izkazalo, da jih imajo. V enem primeru je učiteljica izražala mnenje, da je treba dekletom povedati, kam naj ne hodijo in kako naj se ne oblačijo. Opazili smo, da se na eni od šol uporabljajo dvojna merila za fante in dekleta (ne izrecno in v pravilih, ampak v praksi, denimo glede oblačenja), četudi so zaposleni pojasnjevali, da so vsa šolska pravila nevtralna glede na spol.

Na splošno so bili zaposleni (večinoma učitelji_ce in podporno osebje ali šolski svetovalci_ke) zelo samorefleksivni. Ravno tako so bili motivirani, da bi glede problema spolnega nadlegovanja storili kaj več, ali pa so povedali, da si želijo v prihodnosti preprečiti nespoštljivo in nasilno vedenje na splošno. A glede tega včasih niso bili povsem prepričani in so menili, da niso pristojni za posredovanje. Potrebovali bi več informacij o splošnem pravnem okviru in o veljavnih šolskih protokolih. Na večini delavnic za zaposlene je bila navzoča manjša skupina sodelavcev, ki so bili zelo motivirani za delo. Bili so pripravljeni razmišljati o svojih izkušnjah in primerih, ki so jim bili priča v preteklih letih. Izmenjali so izkušnje o tem, kako jim je bilo v nekaterih primerih nerodno in kako jih je strah posredovati, zlasti, ker niso vedeli, kako se bodo odzvale žrtve. Niso bili prepričani, ali vedo, kaj si žrtve želijo.

\section{Kdo nadleguje, kako, kje in koga}

Skozi oblikovanje konceptualnih zemljevidov so dijaki_nje analizirali razmerja moči, ki pogojujejo spolno nadlegovanje. Poimenovali so celoten spekter možnih nadlegovalcev, od »nezrelih « in »zrelih « oseb do profesorjev, duhovnikov, družinskih članov ter sošolcev. Predvsem dekleta so pogosto povezala vprašanje spolnega nadlegovanja $z$ odnosi moči ter $s$ situacijami večje fizične bližine - denimo v odnosih, ki jih zaznamuje spol, v oskrbi.

Nove tehnologije, ki omogočajo nezaželeno javno izpostavljanje intimnosti, so bile pogosto omenjene kot pasti za spolno nadlegovanje: predvsem družabni mediji in hitra izmenjava posnetkov ter fotografij. Poleg fizičnega in nefizičnega nadlegovanja so udeleženci omenjali tudi verbalno in neverbalno spolno nadlegovanje. Šole, zabave, osamljena mesta, parki, ulice, avtobusi, stranišča itd. so najbolj pogosta mesta nadlegovanja. Fantje in dekleta so večinoma naštevali iste kraje.

Spolno nadlegovanje se lahko zgodi vsakomur, ki je šibek ali zaznan kot šibkejši in ranljivejši, vključno z družinskimi člani, duševno prizadetimi, starejšimi osebami, partnerkami, medicinskimi sestrami, ženskami $\mathrm{z} \gg$ dobro postavo « itd. To ne izključuje moških in fantov, čeprav so najpogostejše žrtve ženske. 
Nadlegovalec ${ }^{8}$ po mnenju dijakov izvaja in čuti prevlado ali celo užitek in zadovoljstvo. Sebe dojema kot močnega in vsemogočnega, medtem ko ima nadzor nad drugim, je $\gg$ kul «, $\gg$ model $\ll$. Žrtev je ponižana in ranjena, osramočena, travmatizirana, pretresena, se slabo počuti, zlorabljena in ne ve, kaj naj stori. Majhna skupina fantov $z$ ene poklicnih šol je menila, da se $\gg$ v nekaterih primerih « žrtev $\gg$ počuti lepo $\ll$. Spolno nadlegovanje je bilo normalizirano kot nujen korak približevanja v odnosih »osvajanja « deklet.

\section{Zakaj ni odziva in kakšen bi lahko bil}

Dijaki in dijakinje se na nadlegovanje le redko odzovejo in običajno ne storijo ničesar, bodisi ker teh dejanj ne štejejo za nadlegovanje, ker se bojijo maščevanja ali ker ne vedo, kam naj se obrnejo in kako pomagati. Prav tako se jim morda ne zdi smiselno odzivati, saj jih drugi-odrasli ne poslušajo ali ne jemljejo resno in se jim ne morejo zaupati. Sramujejo se in ne vedo, na koga naj se obrnejo (dijakinje), ne želijo se vmešavati, poleg tega pa je nadlegovalec lahko njihov prijatelj (dijaki).

Seznam možnih odzivov na nadlegovanje, ki so jih našteli dijaki in dijakinje, zajema: obrniti se na socialnega delavca, poklicati policijo ali učitelja, povedati drugim, odločno se postaviti na žrtvino stran, o dogodku se pogovoriti z žrtvijo oziroma nadlegovalcem ali pa se celo neposredno vmešati. Fantje bi se neposredno soočili z nadlegovalcem, poklicali policijo in starše, dekleta pa bi se zaupala prijateljem, poiskala bi pomoč, povedala profesorju ali drugemu odraslemu oziroma staršem, obvestila bi socialne službe, pomagala bi žrtvi, se pogovorila z žrtvijo.

Dijaki in dijakinje menijo, da učitelji_ce ničesar ne storijo, ker jih večina spolnega nadlegovanja ne jemlje resno oziroma ne verjamejo ali ne opazijo, da se dogaja. Nimajo dovolj znanja o tem, kako se odzvati, ali se $s$ tem ne želijo ukvarjati in se pogosto bojijo posledic. Morda so lahko tudi sami nadlegovalci ali pa jim preprosto ni mar. Dijaki_nje menijo, da učitelji_ce niso dovolj usposobljeni_e; niti ne razumejo, kaj se dogaja, niti ne želijo biti odgovorni_e. Navsezadnje, morda niti nimajo časa, da bi se $s$ tem ukvarjali_e. Učitelji_ce ne posredujejo, ker niso prepričani_e, komu naj verjamejo, in mislijo, da je spolno nadlegovanje težko dokazati, ter se nočejo vmešavati, če ne poznajo celotne zgodbe. Menijo, da jih to ne zadeva, ali pa imajo premalo časa in so pod stresom. Lahko jih je sram in se ne upajo odzvati, češ da si žrtev ne želi njihovega odziva, ali pa se bojijo, da bodo povzročili več škode kot koristi (so dejale dijakinje). 
Po mnenju fantov bi učitelji_ce lahko storili veliko stvari: opozorili nadlegovalca, obvestili njegove starše, spregovorili o spolnem nadlegovanju, sprejeli kazenske ukrepe, poročali socialni službi, obvestili svetovalno službo ali policijo, se vključili, svetovali. Po mnenju deklet pa bi lahko učitelji_ce govorili s povzročiteljem, namenili svoj čas žrtvi, ji prisluhnili, obvestili starše ali policijo, posegli v situacijo, ponudili pomoč, dali nasvet, se pogovorili ali kaznovali.

Dijaki so zvečine navedli naslednje občutke glede žrtve: žal jim je bilo zanjo, želeli so ji pomagati, sočustvovali so z njo: žrtev je uboga, bila je izrabljena, zlorabljena, tega si ni zaslužila. Dijakinje so žrtve dojemale kot nemočne, osramočene, prestrašene, uboge, izpostavljene, potrebne razumevanja in pomoči, kot žalostne, izrabljene in kot nekoga, ki bo imel dolgotrajne posledice (travme). Dijaki in dijakinje so bili zaskrbljeni za žrtev in so ji želeli pomagati. Fantje so pokazali manj empatije, čeprav so se tako dijaki kot tudi dijakinje pogosto osredotočili predvsem na svoja čustva in ne na morebitno žrtvino čustvovanje.

Kot glavni oviri za ukrepanje dijakov sta bila navedena strah pred sankcijami in brezbrižnost, zlasti ko gre za žrtve, ki so neznanci. Navajali so tudi nepredvidljivost, medvrstniški pritisk, problem izpostavljanja, učiteljeve_ičine sankcije, dvojna merila za dekleta in fante, problem dokazovanja dejanja. Tiste, ki o dogajanju na šoli pripovedujejo staršem, učitelji_ ce označujejo kot preveč zaščitene ali »razvajene otroke«. Ovire so tudi brezbrižnost učiteljev in učiteljic, norma nevmešavanja v zadeve drugih, strah pred odgovornostjo, neizkušenost, nemoč in nevednost. Največji oviri sta sramota zaradi izpostavljenosti ter strah, da jih ne bo nihče vzel resno, ali da se bodo tisti, ki jim bodo povedali, pretirano odzvali in bodo naredili več škode.

Odziv na spolno nadlegovanje bi moral biti hiter. Dijaki in dijakinje so predlagali vključitev staršev, pogovor s sošolcem_ko, večjo pozornost, iskanje podpore in pomoči, obveščanje drugih, pogovor o spolnem nadlegovanju, obveščanje učiteljev, policije ali staršev in stik z drugimi ustanovami. Opozorili so, da veliko lažje ukrepamo, če se žrtev na ukrepanje odzove pozitivno, če se odzove več ljudi in če opazovalec_ka pozna žrtev. Žrtvi je treba pomagati in se z njo pogovarjati ter sprožiti skupinsko akcijo, zlasti če je povzročitelj nekdo z močjo. To olajša odziv, saj se človek v skupini počuti podprt in zaupa drugim.

Med zaposlenimi so bili navedeni razlogi za neodzivanje večinoma podobni tistim, ki so jih našteli dijaki in dijakinje. Pri razpravi o tem, kaj lahko storijo, so učitelji in učiteljice navedli, da ne vedo, kdaj gre za kaznivo dejanje, in da se sprašujejo, kaj lahko storijo v takih primerih. Še vedno se nagibajo k odzivanju na spolno nadlegovanje z izpostavljanjem žrtve in 
spraševanjem. Zvečine sploh ne vedo, kako naj se odzovejo. Če bi se soočili s spletnim nadlegovanjem, bi nekateri dijakom zasegli telefone itd. V številnih primerih bi žrtev napotili k nekomu drugemu, svetovalni službi ali zunanji organizaciji. Večina učiteljev si želi dobiti konkretne smernice o tem, kaj je treba storiti in kako se odzvati. Na vseh delavnicah so bile izražene potrebe po protokolih in smernicah, četudi so vsi poudarili, da je pomembno najprej zaščititi žrtev in šele nato ukrepati naprej.

Ovire za ukrepanje pri zaposlenih so predvsem strah pred tožbami in javnimi občili, strah pred prenagljenim obtoževanjem ljudi, bojazen, da ne prepoznajo, ali dekletu fantovo vedenje godi ali ga dojema kot nadlegovanje in se samo trudi delovati mirna brez izražanja strahu ali jeze. Menijo, da do spolnega nadlegovanja po navadi prihaja takrat, ko niso prisotni, zato tudi ne morejo posredovati. Poudarjajo tudi problem pomanjkanja časa.

V primeru, ko bi šlo za povzročitelja_ico, ki je učitelj_ica, bi zadevo obravnavali brez kompromisov. Učitelji_ce za ustrezno odzivanje potrebujejo primerno podporno okolje, $\mathrm{v}$ katerem se počutijo varne - da se lahko posvetujejo s strokovnjakom in zaupno osebo, ter da lahko računajo na podporo zunaj šole, predvsem s strani tistih, ki vedo, kako ravnati v primerih spolnega nadlegovanja in spolnega nasilja, ter dobro poznajo zakonodajo.

Konceptni zemljevidi so pokazali, kako dijaki_nje vidijo odnos do spolnega nadlegovanja v odnosih med dijaki in dijakinjami ter med učitelji in dijaki: menijo, da dijaki ne ukrepajo, ker ne vedo, kaj storiti, ali ker soglašajo $\mathrm{z}$ nadlegovanjem. $\mathrm{V}$ razpravi o »aktivnem opazovalcu_ki« po ogledu videoposnetka je bila ena od njihovih glavnih poant: »Če se vpleteš, jo lahko skupiš.« Učitelji pa se po njihovem mnenju ne odzivajo, ker se ne želijo ukvarjati s temi vprašanji in ker ne vedo, kaj storiti, ali pa celo sami nadlegujejo.

Glavne ugotovitve iz poteka delavnic in raziskave so naslednje:

- Tako dijakinje kot tudi dijaki opažajo, doživljajo in poznajo spolno nadlegovanje ter so kritični do tega pojava $\mathrm{v}$ šoli in zunaj nje.

- Življenja in pričakovanja mladih so tesno povezana s spolom, česar se večinoma zavedajo in so kritični do tega, so pa zaznavne razlike med stališči fantov in deklet. Obenem je razvidno, da v šolah poteka zelo malo razprav o odnosih med spoloma, o problemu hegemonske moškosti in o s tem povezani hierarhiji moči. Tako dijaki_nje kot tudi zaposleni_e ne razumejo dovolj mehanizmov vpliva spola na spolno nadlegovanje in nasilje. 
- Dijaki_nje soglašajo, da spolni in drugi stereotipi vplivajo na naša dejanja, na primer na predstave o tem, kdaj je »primerno « spregovoriti in ukrepati in kdaj ne. Strah in/ali nelagodje sta med najpogostejšimi vzroki neukrepanja ob spolnem nadlegovanju.

- Še vedno se ohranjajo stereotipi, po katerih so za spolno nadlegovanje in nasilje (na primer $\mathrm{v}$ zvezi $\mathrm{z}$ načinom oblačenja, vedenjem itd.) krive žrtve, vendar udeleženci_ke programa kažejo večjo podporo žrtvam in zahtevajo odgovornost od povzročiteljev_ic in širše družbe.

- Družabna omrežja in spletno okolje se dojemajo kot najpogostejši kraji, kjer prihaja do spolnega nadlegovanja in prek katerih je žrtev še bolj stigmatizirana. Vendar gre pri tem lahko za relativno, subjektivno zaznavo, zlasti zaradi dejstva, da virtualna okolja večinoma »izražajo « dejanske odnose v razredu, na ulici, javnem prevozu in širše, nato pa na te odnose še dodatno vplivajo.

- Dijaki_nje si želijo sprememb v zvezi s spolnim nadlegovanjem, vendar ne vedo, kako bi jih sprožili_e. Zelo kritični_e so do neukrepanja učiteljev_ic in odraslih na splošno. Soočajo se s primeri spolnega nadlegovanja s strani učiteljev_ic, ki se v šolah ne problematizira.

- Mladi si želijo več razprave o teh temah in so bili pripravljeni sodelovati v aktivnostih, ki podpirajo pristop opazovalcev_k. Menijo, da če bi se odzvalo več ljudi, bi bilo spolno nadlegovanje precej lažje obravnavati.

- Povsod je bila izražena potreba, da šole razvijejo smernice ali protokole za obravnavanje spolnega nadlegovanja, ki bi vključevali vlogo aktivnih opazovalcev_k.

- Tudi zaposleni_e oziroma učitelji_ce si želijo sprememb, vendar imajo premalo znanja o tem, kako ravnati, še posebej slabo pa poznajo pravni okvir ter vire institucionalne podpore, ki jo lahko dobijo.

- Učitelji_ce so soglašali_e, da je treba spolno nadlegovanje obravnavati celovito: $\mathrm{v}$ to sodi tudi delo med poukom ter pri posameznih predmetih. Prepričani_e so, da bi morale šole razviti smernice in da potrebujejo več usposabljanja oziroma izobraževanja o teh temah.

- Šole se razlikujejo glede na stopnjo splošnega znanja dijakov_inj. Razlogov za to je lahko več: poleg različnih izhodiščnih znanj jim učni načrt zagotavlja več ali manj predmetov, ki obravnavajo širše vzgojno-izobraževalne cilje, kar očitno vpliva na zaznavo spolnega nadlegovanja. 
- Spol (gender) kot struktura moči in heteroseksualne norme predstavljajo kritično vrzel v znanju zaposlenih in dijakov_inj. Niti spolno nadlegovanje niti spolno nasilje nista vključena $\mathrm{v}$ veljavna šolska pravila in protokole.

\section{Omejitve izsledkov in programa:}

- Ključne ugotovitve bi lahko veljale za večino srednjih šol v Sloveniji, vendar nekaterih vprašanj najverjetneje ni mogoče posplošiti na celotno dijaško populacijo (vse šole v vseh okoljih), saj tudi rezultati kažejo razlike.

- Program (ki je bil razvit) je morda primernejši za štiriletne srednješolske programe in bi moral biti še bolj prilagojen za poklicne šole.

- Večina dijakov_inj je sodelovala v programih oziroma delavnicah v okviru rednega pouka. Ko je bilo treba več notranje motivacije za nadaljnje aktivnosti zunaj pouka, sta se njihov interes in volja do ukrepanja zmanjšala.

- Učitelji_ce in drugi zaposleni, ki so sodelovali $\mathrm{v}$ programu opazovalcev_k, so tisti, ki so tudi sicer najbolj motivirani in se ukvarjajo $\mathrm{z}$ več drugimi obšolskimi dejavnostmi. Izziv, s katerim se program ni spoprijel, je bil, kako doseči manj motivirane, manjkajoče zaposlene.

- $\quad$ Razvoj protokolov na vsaki šoli je odvisen tudi od aktivnosti in načrtov Ministrstva za izobraževanje, šolstvo in šport. Pri predstavnikih_cah ministrstva nismo mogli vzbuditi globljega zanimanja za sodelovanje. Povedali so, da delajo več na ravni osnovnih šol, ne pa tudi v srednjih šolah; njihovo stališče je, da so srednje šole bolj osredinjene na prenos znanja in se ne ukvarjajo toliko $\mathrm{z}$ vprašanji »čiste vzgoje. $^{10}$

9 Merim na to, kar se v slovenskem prevodu običajno navaja kot »družbeni spol«. Termina »družbeni spol « ne uporabljam, ker ustvari napačno predstavo o »predobstoječem « bio-

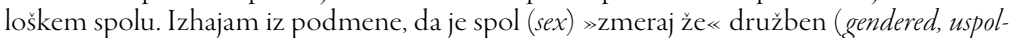
jen) in da ne obstaja nobena esencialna, naravna osnova (sex), na katero bi bil »družbeni« spol naknadno »pripet «. Pri tem se opiram na izvirni tekst, v katerem je bil koncept seks/ spol (sex/gender) prvič tematiziran (Rubin, 1975), ter na novejše razprave pri denimo Butler (1990, 2004). Spol lahko razumemo manj statično predvsem kot proces, torej »uspoljevanje (gendering) različnih dimenzij. S tem presežemo dilemo dihotomija ali mnoštvo spolov, saj nas pri uspoljevanju zanimajo razmerja moči, ki so načeloma lahko popolnoma »odlepljena « od na videz statičnih označevalcev - govorimo o uspoljenosti institucij, norm in organizacij, zanima pa nas njihov sistematično »uspoljen« sistem odnosov moči (Evelyne in Bacchi, 2005: 508). Za več o pojmih spol/sex/gender, njihovih pomenih ter političnih razsežnostih prim. Jalušič, 2009: 52 in nasl.).

Res je, da so bile v Sloveniji leta 2018 v času zadnjega dela projekta, ko so potekale nadaljevalne aktivnosti in sklepni seminar, volitve, kar pomeni, da je do imenovanja novega ministra za to področje preteklo več mesecev. 


\section{Razprava $^{\text {II }}$}

»O spolnem nadlegovanju bi bilo dobro govoriti med poukom in dobiti več znanja. Tako bi se več dijakov zavedalo, da se to dogaja, in potem bi lahko pomagali.«(dijakinja, šola 2)

»Drugi bi morali biti bolj angažirani, na primer profesorji. Nato bi se lahko po pomoč obrnili na nekatere učitelje in bi ukrepali.«(dijak, šola 2)

Raziskovalci_ke in izvajalci_ke delavnic tega projekta smo imeli izvrstno priložnost za sodelovanje s tremi od le peščice srednjih šol v Sloveniji, ki spolno nasilje in spolno nadlegovanje prepoznavajo kot problem, ki bi v šolah zahteval večjo pozornost zaposlenih, dijakov_inj in drugih ustanov. Na samem začetku projekta v letu 2016 Ministrstvo za izobraževanje, znanost in šport ni pokazalo posebnega zanimanja za to temo, tako da tudi nismo mogli priti do odgovornih oseb, ki bi se z nami pogovarjale, ko smo iskali podatke za izhodiščno študijo slovenskega konteksta. Niso razpolagali s podatki in niso imeli informacij o obstoječih raziskavah o spolnem nadlegovanju $\mathrm{v}$ šolah, o projektih, ukrepih, pravilih in dobrih praksah. Omenili so, da so osnovne šole bolj vključene v programe, kjer opravljajo več dela v zvezi z izobraževanjem učencev_k kot del splošnih šolskih programov in kjer poučevanje ni namenjeno predvsem pridobivanju znanja. Medtem pa je v srednjih šolah vsak učitelj_ica odgovoren_a predvsem za poučevanje svojega predmeta; le razrednik_čarka je odgovoren_a za vzgojo, vedenje, medčloveške odnose, disciplino in etiko.

Poleg tega velja omeniti, da so splošni srednješolski predpisi, ki so v Sloveniji veljali od 24. julija 2010 do I. septembra 20I8, fizično in psihično nasilje v šoli sicer izrecno prepovedovali, vendar spolnega nasilja sploh niso omenjali. Tudi nova šolska pravila (veljavna od septembra 2018 dalje, glej Protokol 20r8) spolnega nasilja ne omenjajo izrecno. Navajajo le, da je šola dolžna poučiti dijake_inje o različnih vrstah nasilja, izrecna prepoved pa ne vključuje spolnega nasilja (Pravilnik o šolskem redu, 20I8). Na podlagi tega lahko ugotovimo, da odgovorni_e uslužbenici_ke na Ministrstvu za izobraževanje, znanost in šport ne prepozna(va)jo problema spolnega nasilja ali spolnega nadlegovanja $\mathrm{v}$ srednji šoli. Ker mu ne pripisujejo nobenega posebnega pomena, tudi ne predvidevajo ukrepov za obvladovanje in preprečevanje tega problema, posledično pa ga tudi ne morejo obravnavati, vsaj ne sistemsko.

Tak odnos seveda ni samo problem Ministrstva za izobraževanje, znanost in šport, temveč je simptomatičen za družbo kot celoto in vpliva

II Dva odstavka tega premisleka sta utemeljena na zapisih za sklepno konferenco projekta v Ljubljani, ki jih je pripravila Katja Zabukovec Kerin. 
na prizadevanja na področju preprečevanja, pa tudi na uspešno izvajanje projektov in programov, kot je denimo pristop opazovalcev_k.

$\mathrm{Z}$ navedenimi informacijami želim uokviriti zaključno refleksijo in podajanje nekaterih sklepnih opažanj, ki izhajajo iz naše analize delavnic in izvedbe celotnega programa, zlasti iz analize konceptnih zemljevidov in anket pred izvedbo programa, po njem in naknadnih anket. Rezultati te namreč kažejo, da je večina dijakov_inj in zaposlenih med izvajanjem projekta pridobila več znanja o spolnem nadlegovanju, nadlegovalcih_ kah, o tem, kje se nadlegovanje dogaja, ter o škodi in posledicah nadlegovanja za žrtve. Hkrati tudi bolje razumejo ovire za odziv in ukrepe ter zakaj so opazovalci_ke v glavnem neaktivni.

Delavnice so pokazale, da se učitelji_ce v srednjih šolah pogosto čutijo nemočni_e, ko se soočajo s spolnim nasiljem in nadlegovanjem. $\mathrm{Ne}$ vedo, kaj naj storijo ali kakšno vlogo naj imajo v šoli; naj bi zgolj zagotavljali znanje ali vzgajali? Posledično odzivi pogosto temeljijo na njihovi lastni osebni izkušnji (z nasiljem, z dijaki_njami, z vodstvom, s socialnimi službami - centri za socialno delo, s policijo, s sodišči, s povzročitelji_cami) ter z njihovim individualnim znanjem in občutki. Učiteljski kolektivi in ostalo osebje nimajo enotnega stališča glede dolžnosti šole, nobenega predpisanega ravnanja, različne skupine imajo pogosto nasprotujoča stališča in po veliko hrupa se praviloma nič ne zgodi. Učitelji_ce in ostalo osebje se tudi bojijo, da bodo naredili_e napake ali pa da je to, kar počnejo, napačno - iz različnih že navedenih razlogov. Vodstva šol ali ravnatelji_ce se med drugim bojijo tudi tožb staršev, inšpekcij in javnih občil.ı2 Pozornost je tako pogosto namenjena problemom odraslih in ne žrtvam. Kadar nadlegovani dijak oziroma dijakinja ne dobi ustrezne pomoči, to pomeni, da ima še eno slabo izkušnjo z odraslimi, predvsem pa ostane nezaščiten_a. Šola tako postane sovražno okolje, v katerem ni mogoče dosegati učnih ciljev. Zdi se, da ni mogoče storiti ničesar in da učitelji_ce ne vedo, kako pomagati. Neukrepanje proti nasilju krepi prepričanje mladih, da nikomur ni mar, da nihče nima znanja in ne želi ukrepati, nasilje in nadlegovanje pa ostajata nerazkriti in skriti vprašanji. To še dodatno krepi v javnosti zasidrano splošno prepričanje, da nasilja in nadlegovanja v resnici ni ter da ljudje pretiravajo, ko o tem spregovorijo.

I2 Da je tak strah upravičen, kaže dogodek, ko je bil v Sloveniji že upokojeni ravnatelj osnovne šole priveden pred sodišče, ker je zaščitil dve dekleti, ki sta bili žrtvi nasilja in spolnega napada s strani svojih vrstnikov (povzročiteljema je onemogočil udeležbo na končnem izletu in valeti). O zadevi je potekala intenzivna razprava v javnih občilih in uporabljena je bila tudi v politične namene. Nazadnje je tožilec zadevo zavrgel (prim. Dnevnik, 2018). 
Rezultati izvajanja programa opazovalcev so pomembni za vzpostavitev sistema preprečevanja spolnega nadlegovanja in za oblikovanje pravil ravnanja odraslih. Dijaki_nje so namreč zelo kritični_e do ravnanja učiteljev_ic in odraslih ter njihovih odzivov na spolno nadlegovanje $\mathrm{v}$ šoli, na javnih mestih in doma. Vedo, da so spol in neenaka razmerja moči ključna vprašanja spolnega nadlegovanja, vendar še vedno ne razumejo bistvenih povezav med njimi, oziroma o tem nimajo globljega razumevanja. Prav tako se bojijo govoriti o spolnem nadlegovanju, saj menijo, da jim nihče ne bo verjel in da bodo preveč izpostavljeni. Zaposleni so frustrirani zaradi občutka pomanjkanja kompetentnosti in kritičnosti do lastnega znanja o spolnem nadlegovanju in spolnem nasilju na splošno. Zavedajo se, da potrebujejo pomoč in podporo tako v šoli, med sodelavci_kami, kot tudi zunaj šole.

V treh šolah, na katerih je potekal projekt, je bila izražena velika potreba po razvoju smernic ali protokolov za obravnavanje spolnega nasilja in spolnega nadlegovanja, ki vključuje opredelitev vloge aktivnih opazovalcev_k. Šole potrebujejo pomoč in dolgoročno podporo, da bi lahko učitelji_ce in dijaki skupaj oblikovali te smernice. Da bi bili samoiniciativnost in skupna prizadevanja učiteljev_ic ter dijakov_inj dobrodošli in bi uživali podporo le-ti potrebujejo jasna sporočila in podporo pristojnih institucij, zlasti Ministrstva za šolstvo, česar trenutno niso deležni. $\mathrm{V}$ projektu smo načrtovali oblikovanje smernic, ki bi težile $\mathrm{k}$ vsešolske$\mathrm{mu}$ (celovitemu) pristopu. Vendar smo samo v eni od šol (splošne usmeritve) uspeli skupaj z dijaki_njami in zaposlenimi razpravljati o spreminjanju šolskih pravil, tako da bi le-ta vsebovala tudi smernice za obravnavanje spolnega nasilja in spolnega nadlegovanja. Zaposleni so pričakovali, da bodo smernice za delovanje dobili od $\gg$ zgoraj « torej od pristojnih državnih institucij.

Pretekle študije kažejo, da v Sloveniji zaposleni in dijaki šolskih pravil (še vedno) ne oblikujejo skupaj, da nekateri zaposleni še vedno pričakujejo, da bodo šolska pravila oziroma normativni režim služila predvsem discipliniranju dijakov_inj, ter da ne obstaja dovolj zavedanja o prepletenosti odgovornosti in pravic učiteljev_ic in dijakov_inj. Analiza formalnih dokumentov na ravni poklicnih in strokovnih šol izpred desetih let je pokazala, da šolski dokumenti še vedno samo sledijo nacionalnim pravilnikom, na šolah pa ni dovolj specifičnega strokovnega znanja, ki bi omogočilo oblikovanje vsešolskega vzgojnega pristopa (prim. Peček Čuk, Klarič, Vončina, Mažgon in Kroflič, 2009: 99-105).

Pristop opazovalcev_k si prizadeva pomagati dijakom in dijakinjam, da prepoznajo spolno nadlegovanje in ga obravnavajo kot nesprejemljivega, kar se je izkazalo za uspešno na naših delavnicah, čeprav so 
bile stopnje (ne)sprejemljivosti formulirane različno. Mladi so se lahko na skrbno načrtovanih in vodenih delavnicah učili iz izkušenj drugih in so dobili spodbudo, da prepoznajo pasti, ki so lastne vsakdanjim obravnavam spolnega nadlegovanja, češ da gre samo za šalo ali težavico, ki ni vredna pozornosti.

Evalvacijska raziskava je pokazala, da kljub boljšemu poznavanju spolnega nadlegovanja s strani dijakov_inj in zaposlenih po izvedenem programu nihče od njih ne razume bistveno bolje kot prej, kako spol vpliva na spolno nadlegovanje $\mathrm{v}$ šoli in širši okolici.13 Poleg tega (kljub skrbnemu izvajanju programa in nadaljnjim aktivnostim, ki so jih sami sprožili) še vedno mislijo, da nimajo specifičnega znanja o tem, kaj storiti v konkretnih primerih spolnega nadlegovanja, in da tudi nimajo podpore. Medtem ko so bili opolnomočeni z večjim znanjem o spolnem nadlegovanju, očitno niso pridobili dovolj zaupanja glede tega, kako se odzvati, čeprav so sami opredelili veliko preprostih načinov, kako bi bilo mogoče posegati na primer nameniti nekaj besed žrtvi ali povzročitelju, vključiti učitelje_ ice, starše ali druge ali povedati prijatelju, da snemanje in deljenje videoposnetkov intimnih delov deklet ni šala.

Da ni dovolj samozaupanja, je razumljivo, še zlasti če upoštevamo obstoječi izobraževalni kontekst, ki je povezan s širino učnega načrta, šolskimi politikami, stališči učiteljev_ic, kakovostjo poučevanja in učenja, učiteljsko zmožnostjo vključevanja in prenosa zunajšolskega znanja ter angažiranostjo učiteljev_ic - ali jim dijaki_nje zaupajo, kakšno je njihovo dojemanje spolnega nadlegovanja in spolne enakosti ter kako šola na splošno deluje kot institucija (kakšni so hierarhija, disciplina in medčloveški odnosi). Na rezoniranje in samozaupanje dijakov in dijakinj namreč vpliva celotno šolsko okolje, vključno s starši, javnimi občili ter družbenim in kulturnim okoljem - gre za vprašanje, ali to okolje prispeva k splošnoizobraževalnim ciljem, ki bi vključevali tudi razumevanje, kako jih opredeljuje dimenzija spola. Rezultati so pokazali, da je bilo v šolah z ožjim učnim načrtom (tj. v poklicnih šolah), ki vsebuje manj družboslovnih znanj, in na katere se vpisujejo dijaki s slabšim znanjem in socialnim statusom, več težav pri izvajanju delavnic, saj je bilo veliko manj razumevanja ciljev delavnic kot drugje. $V$ enem primeru skupine fantov smo se soočili celo z odkritim obtoževanjem žrtev spolnega nadlegovanja (»žrtev se počuti lepo «, prim. zgoraj) in s sovražnimi pripombami, kar je mogoče razložiti tudi s problematiko odsotnosti vzgojnega elementa iz kurikuluma te vrste šol (glede tega prim. Kroflič in Peček Čuk, 2009: I8 in nasl.).

I3 I62 dijakov in dijakinj je (v različnih fazah) izpolnilo vprašalnike pred izvedbo programa, po njej in naknadne vprašalnike. Tudi zaposleni so odgovarjali na vprašanja, in sicer pred izvedbo programa in po njej, vprašalnik pa je vrnilo 28 oseb. 
Tudi nekoliko konservativen (sicer impliciten) odnos do oblačenja deklet $v$ eni od šol bi lahko izhajal iz izobraževalnega konteksta. Gre za tradicionalno hierarhijo, ki je značilna za nekatere poklice. Konservativnejša stališča deklet $\mathrm{v}$ tej šoli bi lahko nakazovala, kaj jim je posredovano prek skritega poklicnega kurikuluma o nadlegovanju, ki je prisotno, ni pa pripoznano $\mathrm{v}$ šoli in $\mathrm{v}$ praksi številnih poklicnih ustanov. Nekatere razlike $\mathrm{v}$ odnosu dijakov in dijakinj do spolnega nadlegovanja lahko izhajajo tako iz narave in strukturiranosti vzgojno-izobraževalnega sistema in posebnosti šole ter njenega okolja kot tudi iz političnih in kulturnih prepričanj staršev, kar je bilo razvidno iz posameznih razprav. Družbeno ozračje, odnos medijev in medvrstniška razmerja vplivajo tudi na razumevanje in odzivanje na spolno nadlegovanje. Očitno je, da dijaki na splošno ( $v$ šoli, doma in drugje) ne dobijo dovolj informacij o spolno strukturiranih odnosih moči. Poleg vpliva staršev (ko govorimo o primerih spolnega nadlegovanja) so namreč pomembne tudi vrstniške skupine in splošno družbeno ozračje.

\section{Sklep}

Okrepiti odgovornost posameznika_ce za človeška dejanja in izboljšati pripravljenost ljudi, da intervenirajo v nasilne situacije in odnose drugih, nikakor ni preprosto, saj je treba ljudi dodatno opolnomočiti in spodbuditi k večji angažiranosti (Bowes-Sperry in O'Leary, 2005; Carmody, 2006). $\mathrm{V}$ šolskem sistemu v Sloveniji je priprava izobraževalnih programov prenesena na šole in učitelje_ice, ki imajo pri tem precejšnjo avtonomijo, saj lahko znaten del (tudi na strokovnih šolah) programa šole prilagodijo specifiki svojega okolja (prim. Peček Čuk, Skubic Ermenc in Kroflič, 2009: 70). Gledano s tega stališča, iniciativa šol in zaposlenih na tem področju ni omejena. A izvajanje programa je med drugim pokazalo, da je zaposlenim in dijakom_injam težko delovati avtonomno in samozavestno, če glavni vzroki spolnega nadlegovanja, in sicer spolna neenakost, stereotipi in heteroseksualne spolne vloge, niso dovolj temeljito obravnavani v celotnem izobraževalnem sistemu v okviru učnih načrtov in drugih (dodatnih) programov ali s posameznimi učitelji_cami.

Tako šola kot celota in njen širši kontekst sta pomembna elementa (ne)preprečevanja spolnega nadlegovanja in spolnega nasilja na splošno. Rezultati programa kažejo na to, da so, če želimo aktivirati opazovalce_ ke, potrebni širši premisleki o razmerjih med individualno odgovornostjo dijakov_inj, da delujejo in se odzovejo, odgovornostjo zaposlenih na šolah ter strukturami, ki širše uokvirjajo posamezne primere nadlegovanja. Treba je poudariti odgovornost širše družbe, zlasti odraslih, za nenasilno okolje $\mathrm{v}$ šolah in na drugih javnih mestih. To pomeni, da je razvoj 
»vsešolskega pristopa « (International Bureau of Education) ključna naloga za tiste, ki so odgovorni za mlade v šolah, da bi preprečili spolno nadlegovanje in nasilje, saj nadlegovanje ni posamezen in osamljen dogodek, temveč sestavni del kontinuuma nasilja in celote odnosov ter struktur spolne neenakosti. V družbi s precejšnjo (neformalno) horizontalno spolno segregacijo (med poklici ter šolami oziroma izobraževalnimi progra$\mathrm{mi})$, ki se križa še s socialno in etnično dimenzijo, $v$ kateri se spolna neenakost sicer šteje za »tako rekoč rešeno « (le nekatera posebna in manjša vprašanja je treba razrešiti ločeno od celote), je to tema, na katero bi se morali osrediniti.

$\mathrm{Na}$ ravni šole pristop aktivnih opazovalcev_k lahko pripomore $\mathrm{k}$ formalizaciji postopkov, kar pomeni, da bi o ključnih vprašanjih razpravljali vnaprej, situacije bi skrbno pretehtali in velike korake bi lahko načrtovali. To bi pomenilo tudi, da v krizi posamezniki ne bi ukrepali impulzivno. Odzvalo bi se namreč več ljudi, in sicer vsak z lastno nalogo, vloge pa bi bile jasno opredeljene in razdeljene. Nihče ne bi ostal prepuščen sam sebi, saj bi bil sistem usklajen.

Glavni poudarek bi še naprej veljal zaščiti žrtev in ustavljanju nasilja, hkrati pa bi se osredotočali na stiske zaposlenih, kadar ne vedo, kako se odzvati. Tisti, ki sicer ne storijo ničesar, bi ravno tako morali delovati v okviru usklajenega sistema. Tisti, ki se običajno vključijo v reševanje problemov, bi to počeli v omejenem okviru in bi bili dolgoročno zaščiteni, najpomembnejše naloge pa bi bile opravljene že pred začetkom krize oziroma primerov spolnega nadlegovanja in spolnega nasilja. $S$ tem bi učinkovito zaščitili dijake_inje, zaposlene in šolo, aktivnosti bi tekle bolj gladko in bi bile časovno omejene, vloge pa bi bile razdeljene in različne osebe bi med seboj sodelovale.

Če povzamem, je spolno nadlegovanje sporen koncept, ki ga definirajo kot nesprejemljivo ravnanje spolne narave (fizično, verbalno in neverbalno vsiljevanje, ki vključuje socialna omrežja), ki ga žrtev doživi kot vsiljivo in ogrožujoče. Zajema širši spekter vsiljivih ravnanj, ki so povezana $z$ odnosi moči, spolno hierarhijo in imajo posledice za osebni razvoj ter zdravje žrtve, zato ni mogoče vnaprej predvideti, kako bo ta ravnanja doživela. V vsakdanjem življenju se v kontekstu družbenih, kulturnih in medosebnih odnosov moč in dominacija uveljavljata posredno in netransparentno. Otroci so socializirani v prevladujoče kategorije spola, seksualnosti, kulture, narodnosti in rase. Za uspeh programov preprečevanja spolnega nadlegovanja je ravno zaradi tega pomembno, da se v šolah razvijeta pedagoško okolje in izobraževalni pristop, ki omogočata, da se odnosi moči in strukture dominacije identificirajo, poimenujejo in problematizirajo. Samo v takšnem okolju bo vednost, ki jo pridobijo dijaki_nje iz 
lastne izkušnje vsakdanjega življenja, aktivirana v smeri boljšega razumevanja njihove pozicije v odnosih moči in želje po spremembi.

Spolno nasilje in spolno nadlegovanje sta posledici spolne neenakosti, hegemonske moškosti in s tem povezanih hierarhij, hkrati pa pomagata ohranjati status quo v določeni skupnosti. Z neupoštevanjem te resničnosti problema ne moremo reševati niti temeljito niti sistematično, temveč le delno. Kolikor celoten sistem in njegovi_e akterji_ke domnevajo, da spolna neenakost več ni problem, in trdijo, da lahko problem spolnega nasilja in nadlegovanja rešujejo nekje »zunaj《 obstoječega družbenega konteksta z delnimi ukrepi, ali če celo omogočajo mobilizacijo v primerih spolnega nadlegovanja $v$ populistične namene, potem ni mogoče uresničevati resnične zaščite žrtev in odpravljati spolnega nasilja ter nadlegovanja.

\section{Literatura}

Bojc, K. (2007) Spolno nasilje v srednjih šolah. Diplomska naloga. Kranj: Fakulteta za organizacijske vede, Univerza v Mariboru. https://dk.um. si/Dokument.php?id=6144 (pridobljeno 5. 5. 2019).

Bowes-Sperry, L. in O'Leary, A. (2005) To act or not to act: the dilemma faced by sexual harassment observers. Academy of Management Review 30(2), str. 288-306.

Banyard, V., Moynihan, M. in Crossman, M. (2009) Reducing sexual violence on campus: the role of student leaders as empowered bystanders. Journal of College Student Development 5o(4), 446-457.

Butler, J. (1990) Gender Trouble: Feminism and the Subversion of Identity. New York: Routledge.

- (2004) Undoing Gender, New York and London: Routledge.

Carmody, M. (2006) Preventing adult sexual violence through education? Current Issues in Criminal Justice 18(2), str. 342-356.

Charmaraman, L. Jones, A. E., Stein, N., Espelage, D. L. (2013) Is It Bullying or Sexual Harassment? Knowledge, Attitudes, and Professional Development Experiences of Middle School Staff. Journal of School Health 83(6), str. 438-444.

Connell, Raewyn (2012) Moškosti. Ljubljana: Krtina.

Council of Europe Convention on Preventing and Combating Violence Against Women and Domestic Violence (2011). Council of Europe. https://rm.coe.int/CoERMPublicCommonSearchServices/ DisplayDCTMContent?documentId=090 000I6804603Ic (pridobljeno 5. 5. 2019).

Council Resolution of 29 May 1990 on the protection of the dignity of women and men at work. Official Journal of the European 
Communities, C 157/1990. https://publications.europa.eu/en/publication-detail/-/publication/f46bidoo-7950-4b6I-a6If-a2205cif66fb (pridobljeno 5. 5. 2019).

de Lijster, G.P.A., Felten, H., Kok, G. et al. (2016) Effects of an Interactive School-Based Program for Preventing Adolescent Sexual Harassment: A Cluster-Randomized Controlled Evaluation Study. Journal of Youth and Adolescence 45 (5), str. 874-886. https://doi.org/10.1007/sio964016-047I-9 (pridobljeno 5. 5. 2019).

Dnevnik (2018) Dušan Merc na zatožni klopi jer je branil žrtvi spolnega napada? https://www.dnevnik.si/1042848426/kronika/dusan-merc-na-zatozni-klopi-ker-je-branil-zrtvi-spolnega-napada (pridobljeno 5. 5. 2019).

European Union Agency for Fundamental Rights (FRA) (2014) Violence against women: an EU-wide survey - Main Results. Luxembourg: Publications Office of the European Union. https://fra.europa.eu/en/ publication/20r4/violence-against-women-eu-wide-survey-main-results-report (pridobljeno 5. 5. 2019).

Eveline, J. and Bacchi, C. (2005) What are We Mainstreaming When We Mainstream Gender? International Feminist Journal of Politics 7 (4), str. 496-512.

Epstein, D. (1997) Keeping them in their place: hetero/sexist harassment, gender and the enforcement of heterosexuality. V: A. Thomas in C. Kitzinger [ur.], Sexual Harassment: Contemporary Feminist Perspectives, str. 154-171. Buckingham: Open University Press.

Hill, C. in Kearl, H. (2011) Crossing the Line: Sexual Harassment at School. Washington: American Association of University Women.

International Bureau of Education (s/d). Whole School Approach. Internet. http://www.ibe.unesco.org/en/glossary-curriculum-terminology/w/whole-school-approach (pridobljeno 5. 5. 2019).

Jalušič, V. (2017) Stretching and Bending the Meanings of Gender in Equality Policies. V: V. Jalušič, M. Ladić, L. Zdravković, K. Zabukovec Kerin, K. Strle, S. Čobec (2017) Developing bystander responses to sexual harassment among young people. Background research: Slovenia. http://www.bystanders.eu/wp-content/uploads/2017/o9/bystanders-background-research-slovenia.pdf (pridobljeno 5. 5. 2019).

Lombardo, E., Meier P., Verloo M. [ur.] (2009) Stretching and Bending Gender Equality: A Discursive Politics Approach, str. 52-67. London: Routledge.

Kelly, L. (1988) Surviving Sexual Violence. Oxford: Polity Press. 
Kroflič, R. in Peček Čuk, M. (2009) Zakaj morajo imeti tudi poklicne in strokovne šole svoj vzgojni koncept? V: R. Kroflič et al. [ur.], Ali poklicne in strokovne šole potrebujejo vzgojni koncept?, str. 13-23. Ljubljana: Center RS za poklicno izobraževanje.

Lešnik Mugnaioni D., Koren A., Logaj V, Brejc M. (2009) Nasilje v šoli. Opredelitev, prepoznavanje, preprečevanje in obravnava. Kranj: Šola za ravnatelje. http://www.solazaravnatelje.si/ISBN/978-96I-6637-24-4. pdf (pridobljeno 5. 5. 2019).

Lundgren, R. in Amin A. (2015) Addressing Intimate Partner Violence and Sexual Violence Among Adolescents: Emerging Evidence of Effectiveness. Journal of Adolescent Health 56 (I), str. S42-S $_{50}$. https:// doi.org/I0.1016/j.jadohealth.2014.08.012 (pridobljeno 5. 5. 2019).

MacKinnon, C. A. (1979) Sexual Harassment of Working Women: A Case of Sex Discrimination. New Haven: Yale University Press.

MacKinnon, C. A. (1987) Feminism Unmodified: Discourses on Life and Law. Harvard University Press.

Magalhães, M. J., Canotilho, A. P. \& Brasil, E. (2007) Gostar de Mim, Gostar de Ti: aprender a prevenir a violência de género. Porto: UMAR.

Magalhães, M.J., Sharp-Jeffs, N., Pontedeira C., Guerreiro A., Kelly L., Felgueiras R. in Silva V. (2017) Literature Review. http://www.bystanders.eu/wp-content/uploads/2017/o9/bystanders-literature-review.pdf (pridobljeno 5. 5. 2019).

Meyer, E. (2008) A Feminist Reframing of Bullying and Harassment: Transforming schools through critical pedagogy. Journal of Education $43(\mathrm{I})$, str. $33-48$.

Peček Čuk, M., Klarič T., Vončina V., Mažgon J. in Kroflič R. (2009) Šolska pravila v poklicnih in strokovnih šolah. V: R. Kroflič et al. [ur.], Ali poklicne in strokovne šole potrebujejo vzgojni koncept?, str. 86-I05. Ljubljana: Center RS za poklicno izobraževanje.

Potter, S., Moynihan, M., Stapleton, J. in Banyard, V. (2009) Empowering Bystanders to Prevent Campus Violence Against Women. Violence Against Women I5(I), str. I06-I2I.

Pravilnik o šolskem redu v srednjih šolah (2018) http://pisrs.si/Pis.web/ pregledPredpisa?id=PRAVI343I (pridobljeno 5. 5. 2019).

Rubin, G. (1975) 'Trafficking in Women: Notes on the 'Political Economy' of Sex.' V: R.R. Reiter [ur.], Toward an Anthropology of Women, str. 157-210. New York and London: Monthly Review Press. 
Schewe P. \& O’Donohue, W. (1993) Rape Prevention: Methodological Problems and New Directions. Clinical Psychology Review 13, str. 667-682.

Stanko, E. A. (1985) Intimate Intrusions: Women's Experience of Male Violence. London: Unwin Hyman.

Timmerman, G. (2003) Sexual Harassment of Adolescents Perpetrated by Teachers and by Peers: An Exploration of the Dynamics of Power, Culture and Gender in Secondary Schools. Sex Roles 48(5/6), str. 23I-244.

United Nations (1993) Declaration of the Elimination of Violence against Women. Resolution $48 / 104$ of 20 December 1993, http://www.un.org/ womenwatch/daw/vaw/reports.htm (pridobljeno 5. 5. 2019).

Vera-Gray, F. (2016) Men's stranger intrusions: Rethinking Street Harassment. Women's Studies International Forum 58, str. 9-17.

Women and Equalities Committee (2016) Sexual Harassment and Sexual Violence in Schools. London: House of Commons.

World Health Organization (2002) Sexual Violence. World Report on Violence and Health, str.I 47-18I.

Zakon o ratifikaciji Konvencije Sveta Evrope o preprečevanju nasilja nad ženskami in nasilja v družini ter o boju proti njima (MKPNZND) oz. Istambulska konvencija (20I4), https://www.uradni-list.si/glasilo-uradni-list-rs/vsebina/2015-02-0001/\#Aiding\%C2\%Aoor\%C2\%Aoabettin g\% $2 \%$ Aoand\%C2\%Aoattempt (pridobljeno 5. 5. 2019).

Zavod RS za šolstvo (2016). Protokol ob zanznanvi in za obravnavo medvrstniškega nasilja v šolah. https://safe.si/sites/default/files/protokol_ ob_zaznavi_in_za_obravnavo_medvrstnikega_nasilja_v_viz.pdf (pridobljeno 5. 5. 2019).

Zavod RS za šolstvo (2016a). Navodila s priročnikom za obravnavo medvrstniškega nasilja v vzgojno-izobraževalnih institutcijah. http://www. zrss.si/digitalnaknjiznica/navodila-medvrstnisko-nasilje-viz-20ı16/\#2 (pridobljeno 5. 5. 2019).

International Bureau of Education (s/d). Whole School Approach. Internet. http://www.ibe.unesco.org/en/glossary-curriculum-terminology/w/ whole-school-approach (pridobljeno 5. 5. 2019). 